\title{
ANALYSIS OF COMMUNITY CASH WAQF INTENTION TO SUPPORT SUSTAINABLE DEVELOPMENT GOALS (SDGs): THEORY PLANNED BEHAVIOUR APPROACH
}

\author{
Alif Khuwarazmi' ${ }^{1}$, Silvi Sri Mulyani², Arfi Mulyasa Insani ${ }^{3}$ \\ 1,2,3Department of Sharia Accounting, Faculty of Economics and Islamic Business, Sunan \\ Kalijaga Yogyakarta State Islamic University, Yogyakarta \\ 'Email: alivekhuwarizm@gmail.com (correspondence) \\ 2Email: silvisrimulyani28@gmail.com \\ 3Email: arfiinsani18@gmail.com
}

\begin{abstract}
The SDGs outline 17 goals that are part of the sustainable development agenda. One of the efforts that can be made to alleviate poverty around the world is by utilizing "endowment funds". In Indonesia, financing innovation to alleviate poverty can be done through cash waqf. However, the facts on the ground show that the huge potential for cash waqf cannot be optimally absorbed. Therefore, this study aims to explore and test empirically the extent to which the Indonesian people intend to optimize the potential of cash waqf in an effort to support financing and achieve the goal of poverty alleviation in Indonesia. This is done by identifying the factors that influence the intention of the Indonesian people to contribute cash waqf and correlating this with the influence of public knowledge about waqf, especially the cash waqf itself. The method used in this study is a quantitative method by collecting primary data from as many as 316 Muslim respondents throughout Indonesia. The questionnaire used is an adoption of Theory of Planned Behavior (TPB) with the addition of several variables that influence intention. This approach is used to determine the community's intention to contribute cash waqf. Most of Indonesian Muslim consider the knowledge in the influence of the intention to do cash waqf. The results indicate that there is no significance effect between religiosity and attitude, attitude (attitude towards) people's intention to do cash waqf also between subjective norm and people's intention to do cash waqf. Furthermore, there are five effects are significant with $\mathrm{p}$ value $<0.005$, between ihsan and religiosity, knowledge and attitude, ihsan and attitude, trust and attitude also PBC and people's intention to do cash waqf.
\end{abstract}

Keywords: Cash Waqf, $1^{\text {st }}$ SDGs, TPB, Intention to do Cash Waqf, Poverty 


\section{Introduction}

Sustainable Development Goals (SDGs) are a set of universal sustainable development goals to replace the Millennium Development Goals (MDGs) that will serve as a guide, as well as a framework for international development cooperation until 2030 and are intended to provide a reference for setting national policy priorities. The SDGs consist of 17 goals and 169 targets that balance the economic, social and ecological dimensions of sustainable development, and put the fight against poverty and sustainable development on the same agenda for the first time (Asmalia, Kasri, et al., 2018).

In Indonesia, poverty is tending to be a very crucial problem, it's economic consequences but also causing social problems and domestic political instability. Therefore, poverty alleviation must be a top priority in economic development, both in the short and long term (Pratama, 2015). It is easy enough to argue that we must fight and end poverty, hunger and disease, or fight human-caused climate change (Sachs, 2015), however it is a difficult task. One of the main challenges to achieving SGDs is limited sources of financing.

Funds have traditionally come from government budgets, official development assistance, and loans from multilateral financial institutions. Nonetheless, they are again sufficient resources to achieve the SDGs. The World Economic Forum (2015) estimates that the current investment gap (i.e., the difference between the total investment required and the traditional development funds available) in critical sectors is \$ 3.1 trillion. Therefore, it is necessary to increase sources of funds through partnerships with the private sector, religions and others (Asmalia, Kasri, et al., 2018).

The role of socio-economic and Islamic finance is seen as being in line with and capable of contributing to achieving the Sustainable Development goals (SDGs) as recognized by the G20 institutions, Financing for humanitarian missions, the World Bank, and the Islamic Development Bank (IDB) (Andri Soemitra, 2018).

In pursuit of the 2030 agenda set out in the SDGs, the United Nations Development Program (UNDP) Indonesia has started to undertake a number of works to use Islamic finance in their framework. One of the focuses of UNDP Indonesia's activities related to Islamic finance is efforts to increase the required capacity at the country, regional and international levels, especially in terms of social finance. UNDP has collaborated in research with the Islamic Development Bank Islamic Research and Training Institute (IRTI) (Andri Soemitra, 2018).

As one of the Islamic financial instruments, waqf can be a source of support for this financing because waqf is a socio-economic type of worship, meaning that waqf can play an important role in improving the welfare of Muslims, both in the fields of education, health, social and public services. religion, the development of science and Islamic civilization (Syafiq, 2014a).

The need to achieve this welfare has been discussed in Islamic literature with the concept of maqasid al-sharia (the goal of sharia). The reason for the existence of maqasid al-sharia is to fulfill the interests (jalb al-masalih) of all mankind and avoid danger (dar 'almafasid) (Asmalia, Kasri, et al., 2018). Imam al-Ghazali classified 
maqasid al-sharia into five main categories, namely protection of faith (din), life (nafs), intelligence ('aql), lineage (nasl), and wealth (mal) (Chapra, 2008).

The meaning of waqf in Indonesia has undergone a wider and more complete development (Arif, 2010a). If viewed further, in Law no. 41 of 2004, precisely in Article 16 paragraph (1), it is explained that waqf can be made on immovable and movable objects. This means that money can be donated because it is included in the category of moving objects. Thus, waqf does not only include waqf for immovable objects such as land, buildings, gardens and so on. Rather, it includes moving objects such as money.

As a country with the largest Muslim population in the world, amounting to $87 \%$ or around 230 million people, Indonesia has implemented cash waqf. According to (Nafis, 2009) the Muslim population is a great asset for the collection and development of cash waqf.

Based on data from the Indonesian Waqf Board (BWI), the potential for waqf in Indonesia is currently quite large, reaching IDR 2,000 trillion with an area of 420 thousand hectares of waqf land and IDR 188 trillion in cash waqf. The Ministry of Religious Affairs data shows that the amount of waqf land reaches 161,579 hectares. The area of waqf assets spread over 366,595 locations is the largest number of waqf assets in the world. If this potential can be achieved, it can be used as a turning point for the economic revival of the people (Saptono, 2019).

According to (Nasution \& Hasanah, 2005) the potential for waqf in Indonesia, if it is estimated that the number of generous Muslims is 10 million with an average income of Rp. 500,000 to Rp. 10,000,000, then the estimated calculation of the accumulated cash waqf funds is around 3 trillion.

Based on the opinion of previous researchers regarding the potential of cash waqf in Indonesia, of course there needs to be action to be able to realize and maximize the potential of cash waqf in Indonesia that has been previously calculated. If we look at it in terms of the funds collected, the potential that has been calculated in various previous studies has not been realized properly. This is due to the lack of literacy about cash waqf among the community and the lack of ease in the method of donating money. The methods offered by nazirs - is an individual or legitimate substance that holds the command to keep up and deal with the waqf property as per the structure and reason for the waqf-- from various institutions to pay cash waqf are direct payment at the nazir place and also by direct cash waqf through a savings account that has been agreed at the beginning of the deposit.

Based on this, this study aims to explore and test empirically the extent to which the Indonesian people intend to optimize the potential of cash waqf in an effort to support financing and realize SDGs in Indonesia, especially in the economic sector, namely alleviating poverty. This is done by identifying the factors that influence the intention of the Indonesian people to distribute cash waqf and correlating this with the influence of public knowledge about waqf, especially the cash waqf itself. Researchers assume that to be able to optimize waqf as a whole, people must have a response, a good attitude and an interest in waqf, especially for money waqf. Because of the great potential that Indonesia has through this cash waqf, it must be maximized. 
As far as we are concerned, several studies have attempted to address this issue. Although this may be related to the fact that the SDGs are a relatively new global development agenda that was just issued in 2016, replacing the Millennium Development Goals (MDGs) ending in 2015. Not only that, linking waqf with the SDGs is also a relatively new discourse in Islamic economics.

This study collected primary data from respondents in Indonesia using the Theory of Planned Behaviors (TPB) approach. This approach is used to determine the community's intention to distribute cash waqf. The analytical test tool used is CB-SEM (Covariance Based-Structural Equation Modeling) using AMOS software to analyze primary data.

\section{LITERATURE REVIEW}

\section{Cash Waqf}

In language the word waqf comes from the Arabic verb "waqafa" which means to cause something to stop and be silent. Etymologically, Ibn Manzur explains that waqf means al-habs (holding back). Waqf is a word in the form of masdar (gerund) from the expression waqfu al-syai 'which basically means holding something back. Epistemologically (Arif, 2010b) explains that waqf in Indonesia is interpreted broadly and is taken from various views of scholars. According to Law no. 41 of 2004 waqf is defined as a legal act of wakif to separate or give up part of his property to be used forever or for a certain period of time in accordance with his interests for the purposes of worship and / or general welfare according to sharia. From the definition described above, it can be seen that in improving the welfare of Muslims, both in the fields of education, health care, social and cultural, waqf plays a fairly important role (Syafiq, 2014). In Indonesia, the law of cash waqf is stipulated in Law no. 41 of 2004 Article 16 paragraph (1) which explains that waqf can be made on immovable and movable objects. Movable objects here can fall into the category of liquid objects such as cash / money.

Waqf money has historically been practiced since the beginning of the second century Hijriyah (Syafiq, 2014) but it was not practiced at the time of the Prophet Muhammad. Narrated by Imam Bukhari, one of the leading scholars, Imam az-Zuhri (died $124 \mathrm{H}$ ) argued that the dinar and dirham waakaf could be recommended for the construction of means of da'wah, social, and education for Muslims. This is done by distributing the accumulated cash waqf funds to productive business actors and then the profits afterwards are distributed to mauquf alaihi, so that the initial value of waqf will not be lost or exhausted. Cash waqf has also been practiced during the Caliphate of the Abbasiah Dynasty, the Ayyubid Dynasty to the Ottoman Turks. At that time, cash waqf was used as a fiscal obligation, the main budget, then distributed to social institutions engaged in education, food, clothing and so on (Ambrose et al., 2018).

\section{Sustainable Development Goals}

The Sustainable Development Goals are a joint agenda agreed upon and endorsed by world leaders at the United Nations Headquarters to coincide with the 25 September 2015 SDGs. The SDGs have 17 Goals and 169 targets planned for the next 
15 years. front (valid from 2016 to 2030). This agenda is targeted globally to eradicate all forms of poverty, reduce inequality and protect the environment. SDGs apply to all countries (universal), so that all countries without exception developed countries have a moral obligation to realize the achievement of the goals and targets contained in the SDGs.

In Indonesia, the role of waqf has the potential to realize the ideals of sustainable development goals, especially goal 1, which is to alleviate all forms of poverty, given that the poverty rate in Indonesia tends to be high, which is believed to be 24.7 million poor people or around 9.22\% of the total. population in Indonesia by 2019 (Databoks, 2020) \& (Statistics Indonesia, 2019). In this study, the focus of the logic that was built was cash waqf as a potential financial instrument and was allegedly able to realize the goals of SDGs 1.

\section{Theory of Planned Behaviour (TPB)}

Theory of Planned Behavior (TPB) is a theory developed based on Theory of Reasoned Action (TRA) (Ajzen, 1991). TRA assumes that in behavior, humans will consciously consider all the information around them. A behavior carried out by humans is determined by intention. The intention to do or not take a particular action is influenced by two basic factors, namely attitude (Attitude Towards Behavior) and social influence, namely subjective norms (Ajzen \& Madden, 1986).

Due to the limitations of the original TRA model in predicting behavior, where people have control over the incomplete will, the TPB was developed to overcome measurement weaknesses that cause low correlation between attitudes and behavior (Ramdhani, 2011). TPB emphasizes the factors that influence the nature of a person's behavior. more specifically in the TRA framework, a theory designed to predict and explain a person's behavior in a particular context (Ajzen, 1991).

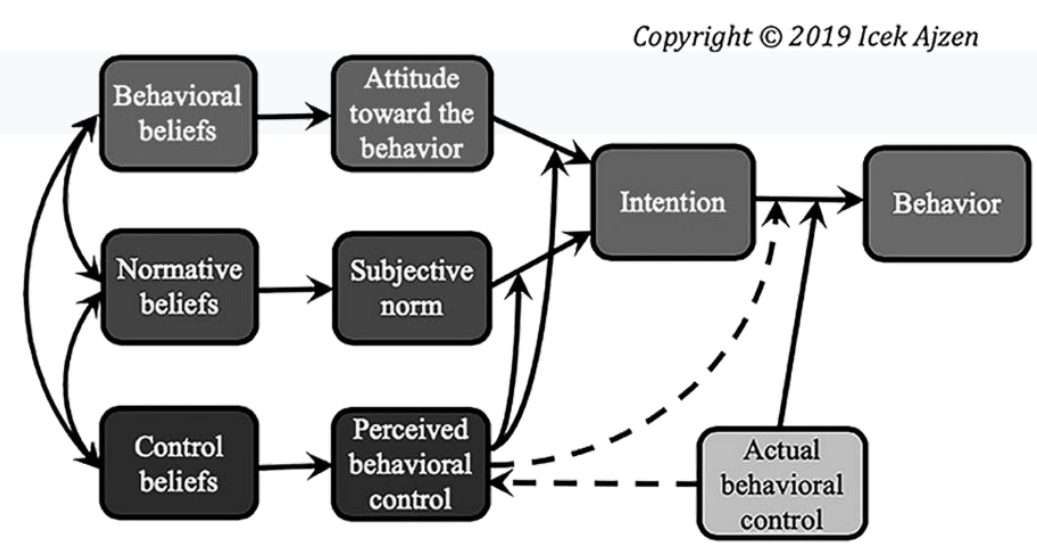

Figure 1. Theory Planned Behaviour by Ajzen (1991)

TPB added the concept of perceived behavior control, which comes from the SelfEfficacy Theory (SET) theory (Ramdhani, 2011). The theory developed by Bandura in 1977 contributed to explaining the various relationships between beliefs, attitudes, 
intentions and behavior. On that basis, the factors that influence behavior in TPB include attitude (Attitude Towards Behavior, Subjective Norm), and Perceived Behavior Control (Ajzen, 2002). These three variables together form and affect individual intentions and behavior (Ajzen, 1991).

\section{Research Hypothesis}

\section{Perceptions of Ihsan and Religiosity}

Ihsan is the nature of the human tendency to do good to parents, siblings, and neighbors. Just like the idea of altruism, the word Ihsan literally means showing compassion for others, especially those who are weak or helpless (Rizal \& Amin, 2017) (Sand1kc1 \& Rice, 2011). As a projection of kindness and generosity, ihsan is a commonly held philosophy that includes compassion, tolerance, justice, care and forgiveness (Khayat, 2006). Ihsan shows a conscience that is always God's attention in every action and behavior. The principle of ihsan correlation and religiosity is contained in the Qur'an chapter Al-Maun verses 1-7 (Rizal \& Amin, 2017). Therefore, the researcher hypothesizes that,

\section{H1: A person's perception of affection affects the level of religiosity}

\section{Ihsan Perceptions and Attitude}

Generous individuals tend to act kind. Quoting from (Al-Qardawi, 1981), (AlQardhawi, 1981) explained that Islam promotes compassion for the needy, the poor and the needy. Almsgiving, waqf and zakat correlate with individual perceptions of ihsan towards others. Helping others by giving is considered as worship that will create a balance for one's satisfaction in managing finances for the world and for the hereafter (Khan, 1986). Researchers hypothesize that the perception of ihsan can influence a person's attitude regarding cash waqf.

H2: Ihsan's perception has a significant positive effect on a person's Attitude on cash waqf

\section{Religiosity and Attitude}

Religiosity measures the extent to which humans follow the path established by God. In Islam, Allah is a substance that there is no God but Him. Individuals with a higher level of religiosity maintain expected patterns of behavior in accordance with religious demands (Johnson et al., 2000). This definition shows that the level of religiosity has an influence on attitude. The level of religiosity is needed to develop the nature of giving, because all religions require giving (charity) (Bassir et al., 2014). As the findings disclosed by (Carabain \& Bekkers, 2011) that Muslim communities who have a high level of religiosity tend to have high charity. (Souiden \& Rani, 2015) argues that religion and attitudes have a correlation, religion contributes to building a knowledge base that justifies and controls a person's attitudes and behavior, a person's religious identity can influence their behavior and attitudes. Therefore, the researcher has the hypothesis that,

H3: Religiosity level has a significant positive effect on a person's attitude towards money waqf 


\section{Trust and Attitude}

Several studies have found that people can indeed lose trust in public institutions or organizations (Doney \& Cannon, 1997), which are non-profit or charities / organizations such as mass organizations, NGOs and so on. Various empirical studies have also discussed a lot about a person's trust relationship with various parties, (Awaliah Kasri \& Ramli, 2019) finding that trust is important to build attitude to charity through the intermediary of non-profit organizations, he found that a person has a tendency to invest in mosques. Researchers conclude that a person's high level of trust in a charitable business organization is in line with one's attitude to give greater alms to the organization concerned. If the researcher correlates the waqf, there is a Nazir institution that deals with the management of funds / waqf sources, the assumption of the researcher is that if the Nazir institution is trustworthy, it will increase people's attitudes to waqf, especially cash waqf. Therefore, in line with previous research, the researcher hypothesizes that:

H4: A person's trust in waqf nazir institutions has a significant positive effect on a person's attitudes towards money waqf

\section{Knowledge and Attitude}

In his book, (Ajzen, 2005) explained that knowledge can affect individual attitudes in doing something. In this study, the knowledge referred to is referring to the knowledge of waqf (which has waqf) about waqf, especially cash waqf, and the use of waqf and its use in realizing the 1st SDGs. Knowledge is an important component that can influence attitudes and perceptions (Awaliah Kasri \& Ramli, 2019). Knowledge has an influence on the behavior of paying zakat (in this case the author adopts for waqf) (Othman et al., 2017). (Awaliah Kasri, 2013) In the case of charities donating, he found that people with higher levels of education tended to do more charity or donations. Therefore, the researcher hypothesizes that:

H5: A person's level of knowledge about money waqf has a significant positive effect on his attitude on money waqf.

\section{Perceived Behavior Control and Intention}

Perceptions of behavioral control have an important role in Theory of Planned Behavior (TPB). The concept of perceived behavior control is in accordance with the concept of self-efficacy put forward by (Bandura, 1982), where a person's behavior is strongly influenced by belief in one's own ability to do something. TPB places the construction of self-efficacy or perceived behavioral control in the framework of a more general relationship between beliefs, attitudes, intentions, and behavior (Ajzen, 1991). There are two reasons that support this hypothesis. First, the intention to try to complete a behavior tends to increase with the perception of behavior control. Second, perceived behavioral control can be used as a substitute for actual control. Perceptions of behavioral control become less realistic when there is little information a person has about what they want to do or when foreign elements enter the behavior situation

(Ajzen, 1991). Therefore, the researcher hypothesizes that: 
H6: Perception of Control A person's behavior towards cash waqf has a positive effect on someone's intention to do cash waqf.

\section{Subjective Norms and Intention}

The influence of other people and the environment has an effect on the attitudes and behavioral intentions of individuals (Ajzen, 1991). The subjective norms in the TPB have the same meaning as the injunctive norms proposed by (Cialdini et al., 1991). The social influence of the individual is influenced by knowledge of what should or should not be done through the means of social norms (White \& Roberson-Nay, 2009). The main source of social influence comes from other people who are important to the individual, such as family members, friends, and neighbors (Ajzen, 1991). Action is a response to social norms because of the tendency to seek relevant approval from others while avoiding their mistakes (White \& Roberson-Nay, 2009). Behavioral adjustments will be made with reference to situational cues if the individual has strong selfmonitoring. Hence, the existence of other people is a precondition for driving changes in behavioral intention (White \& Roberson-Nay, 2009). Therefore, the researcher hypothesizes that,

H7: A person's Subjective Norm towards cash waqf has an influence on someone's intention to do cash waqf

\section{Attitude and Intention}

Attitude towards a behavior can be defined as a person's tendency to judge a behavior whether positive or negative. Based on TPB, attitudes towards a behavior are a consequence of the behavior to be carried out, this is commonly referred to as behavioral intention. Attitude toward a behavior is determined by a combination of subjective norms and perceptions of behavioral control. These two factors can be found in the salient beliefs of a behavior. Salient beliefs are general assumptions used by certain groups to judge behavior. Beliefs influence attitudes in proportion to the subjective probability that behavior will result in questionable outcomes. Several studies have been conducted to examine the effect of attitudes on donating behavior (in this case, waqf) (Al Jaffri Saad \& Haniffa, 2014) found that intention, influenced by subjective attitudes and norms, is a significant predictor of compliance with waqf paying behavior. In other words, intention becomes a mediator in influencing subjective attitudes and norms. Therefore, the researcher hypothesizes that,

H8: A person's attitude towards cash waqf has an influence on someone's intention to do cash waqf 


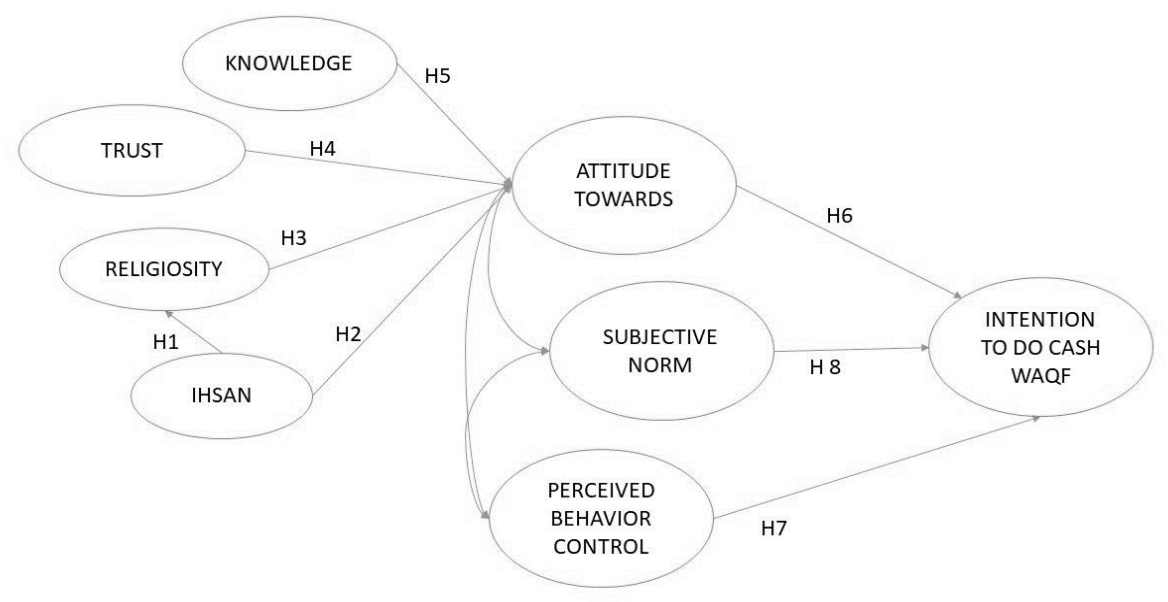

Figure 2.

Adaptation research model from Theory Planned Behavior and (Asmalia, Awaliah Kasri, et al., 2018) with researcher modification

\section{Research Methodology}

\section{Type of Research}

In general, this research is included in a quantitative research framework because it involves the process of collecting data in the form of numbers through a predetermined size scale and then testing the hypothesis through empirical statistics. Cooper and Schindler (2011b, p. 163) explain that quantitative research is research that leads to a process of prediction and theory testing with precise and accurate instruments. Not only that, quantitative research is usually characterized by the existence of hypotheses and statistical testing of the research model.

\section{Data Collection}

The survey method is considered effective and efficient as a method of collecting data to obtain answers from large numbers of respondents quickly and accurately. According to Fink (in Sekaran \& Bougie, 2003, p. 97) research with the survey method is a system or method for collecting information from a number of populations or samples that aims to describe, compare, or explain their knowledge, attitudes and behavior. The instrument used in this survey method is a structured and systematic questionnaire containing a number of questions and statements for each variable in the research model. This questionnaire consists of 8 constructs with a total of 30 items of indicators using a Likert scale of points 1 (strongly disagree) to 5 (strongly agree) to determine individual responses and attitudes to something. Neuman (2006, p. 273) asserts that the survey method is considered appropriate for research that leads to questions to measure a person's beliefs or behavior. In summary, the construct and the number of indicator items that have been adapted and their reference sources are described in the following table: 
Table 1 The Reference Source of the Questionnaire

\begin{tabular}{|c|c|c|c|}
\hline No & Name of the Construct & Item & Reference Source \\
\hline 1 & Ihsan & 5 & \multirow{9}{*}{$\begin{array}{l}\text { Muslim Attitude Towards } \\
\text { Participation In Cash Waqf: } \\
\text { Antecedents And Consequences } \\
\text { (Syadiyah Abdul Shukor dkk, } \\
\text { 2017) } \\
\text { Perceived Behavioral Control, } \\
\text { Self-Efficacy, Locus of Control, } \\
\text { and the Theory of Planned } \\
\text { Behavior (Ajzen, 2002) }\end{array}$} \\
\hline 2 & Religiousity & 7 & \\
\hline 3 & Attitude & 4 & \\
\hline 4 & Trust & 4 & \\
\hline 5 & Knowledge & 4 & \\
\hline 6 & $\begin{array}{l}\text { Perceived Behavior } \\
\text { Control }\end{array}$ & 3 & \\
\hline 7 & Subjective Norm & 3 & \\
\hline 8 & Intention to do Waqf & 3 & \\
\hline & Jumlah Item & 33 & \\
\hline
\end{tabular}

\section{Sampling Technique}

The technique used is Simple Random Sampling, which means that simple random sampling is a sampling technique that is directly carried out on the sampling unit (Margono, 2010). In simple terms, through this technique anyone has the right to become a sample because the chances of each member of the population are equal. Simple Random Sampling is the main alternative for research that prioritizes generalization so that the sample obtained is truly able to represent or represent the results of research in general. The population in this study is the Muslim community in Indonesia.

\section{Data Analysis}

The research model was tested empirically through a statistical approach by adopting the Structural Equation Modeling (SEM) model. There are two fundamental reasons why the SEM model is used in this study, namely: (1) SEM is able to test complex research models simultaneously and (2) SEM is able to measure research variables that cannot be measured directly (unobserved variable) and can detect and calculates the error in measurement. Furthermore, to confirm a standard theory-based study, a popular Covarians-based SEM model was used. This term is often known as CB-SEM.

The selection of CB-SEM was also carried out by considering 2 important things, namely: (1) the researcher uses standardized theory and is often used in behaviorbased research (2) and a relatively complex structural model involving many constructs and measurement indicators that are tested regularly. at the same time.

Next, in hypothesis testing, there are tests of several assumptions, including normality test, reliability test, validity test, model suitability test and hypothesis testing. Collinearity VIF (AFVIF), and Path Coefficient. The guidelines for determining the criteria for acceptance of the results of assumption tests are briefly described below: 
Table 2 Outer Model and Inner Model Criteria

\begin{tabular}{l|l|l|l}
\hline \multicolumn{1}{c}{ Test Model } & $\begin{array}{l}\text { Attributes of the } \\
\text { Measurement } \\
\text { Model }\end{array}$ & $\begin{array}{l}\text { Measurement } \\
\text { Model Output }\end{array}$ & \multicolumn{1}{c}{ Reverence Value } \\
\hline $\begin{array}{l}\text { Test for } \\
\text { normality, } \\
\text { validity, and } \\
\text { reliability }\end{array}$ & $\begin{array}{l}\text { Assesment of } \\
\text { normality }\end{array}$ & $\begin{array}{l}\text { Skewness dan } \\
\text { Kurtosis }\end{array}$ & $\begin{array}{l}\text { If the value on the } \\
\text { skewness of the data is } \\
\text { between }-2.58 \text { to } 2.58 \text { and } \\
\text { the kurtosis value is }<7, \\
\text { then the research data can } \\
\text { be said to be normal } \\
\text { (Waluyo, 2016) }\end{array}$ \\
\cline { 2 - 4 } & $\begin{array}{l}\text { Cronbach's Alpha } \\
\text { Composite } \\
\text { Reliability }\end{array}$ & $\begin{array}{l}\text { Laten Variabel } \\
\text { Coefficient }\end{array}$ & $\begin{array}{l}\text { The value must be above } \\
0.60 \text { (Sholihin \& } \\
\text { Ratmono, 2013) }\end{array}$ \\
\cline { 2 - 4 } & & &
\end{tabular}

\begin{tabular}{l|l|l|l}
\hline Model fit test & Chi Square & Goodness of fit & $\begin{array}{l}\text { Expected small } \\
<0,02\end{array}$ \\
\cline { 2 - 2 } & Probability & & \\
\cline { 2 - 2 } & GFI & & \\
\cline { 2 - 2 } & TLI & $>0,90$ \\
\cline { 2 - 2 } & CMIN/DF & $<2,00$ \\
\cline { 2 - 3 } & Path Coefficient & Path Coefficient & Significance value $\mathrm{P}<$ \\
& & and P Values & $1 \%, 5 \%$ \\
\hline
\end{tabular}

\section{Result and Discussions}

\section{Respondent Characteristic}

Respondents in this study were 316 Muslim communities in all regions of Indonesia. Respondents filled out questionnaires online through the Google form application which the researchers packaged in such a way as to make it easy and efficient in accessing and filling out the questionnaire. The following researchers present the data in table 4 regarding information on the characteristics of the respondents in this study. The majority of respondents were women with a percentage of $62.3 \%$ of the total 316 respondents, while the majority of respondents were in the age range $19-21$ years, which was $70.9 \%$ of the total 316 respondents, for the latest education the majority was high school level, namely $725 \%$ of the total 316 respondents, then the majority income is in the range of less than Rp. 1,000,000, - which is $69 \%$ of the total 316 respondents.

Table 3. Respondent Characteristic

\begin{tabular}{|c|l|c|r|}
\hline Variable & \multicolumn{1}{|c|}{ Description } & Frequency & Percentage $\%$ \\
\hline \multirow{3}{*}{ Gender } & Male & 119 & $37,7 \%$ \\
\cline { 2 - 4 } & Female & 197 & $62,3 \%$ \\
\hline \multirow{5}{*}{ Age } & $19-21$ y.o & 224 & $70,9 \%$ \\
\cline { 2 - 4 } & $22-25$ y.o & 84 & $26,6 \%$ \\
\cline { 2 - 4 } & $26-30$ y.o & 4 & $1,3 \%$ \\
\cline { 2 - 4 } & $31-40$ y.o & 1 & $0,9 \%$ \\
\cline { 2 - 4 } & $>40$ y.o & 1 & $0,3 \%$ \\
\hline \multirow{2}{*}{$\begin{array}{c}\text { Latest } \\
\text { Education }\end{array}$} & Junior High School & 229 & $0,3 \%$ \\
\cline { 2 - 4 } & Senior High School & & $72,5 \%$ \\
\hline
\end{tabular}




\begin{tabular}{|l|l|c|r|}
\hline \multirow{5}{*}{} & Associate Degree & 8 & $2,5 \%$ \\
\cline { 2 - 4 } & Bachelor Degree & 78 & $24,7 \%$ \\
\cline { 2 - 4 } & Graduate & 0 & $0,0 \%$ \\
\cline { 2 - 4 } & Postgraduate & 0 & $0,0 \%$ \\
\hline \multirow{5}{*}{ Income } & $<$ Rp. 1.000 .000 & 217 & $69 \%$ \\
\cline { 2 - 4 } & Rp. $1.000 .000-3.000 .000$ & 86 & $27 \%$ \\
\cline { 2 - 4 } & Rp. $3.000 .000-5.000 .000$ & 9 & $3 \%$ \\
\cline { 2 - 4 } & $>$ Rp. 5.000 .000 & 4 & $1 \%$ \\
\hline
\end{tabular}

\section{Variable Descriptive Statistical Test}

Table 4 Variable Descriptive Statistical Test

\begin{tabular}{|c|l|c|c|c|c|}
\hline No & \multicolumn{1}{|c|}{ Variable } & Min & Maxs & Average & Std.Deviation \\
\hline 1 & Ihsan & 1 & 5 & 4,6557 & 0,45915 \\
\hline 2 & Religiosity & 1 & 5 & 4,73373 & 0,57226 \\
\hline 3 & Attitude Towards & 1 & 5 & 4,207 & 0,498 \\
\hline 4 & Trust & 1 & 5 & 3,983 & 0,547 \\
\hline 5 & Knowledge & 1 & 5 & 3,532 & 0,6 \\
\hline 6 & Perceived Behavior Control & 1 & 5 & 3,889 & 0,406 \\
\hline 7 & Subjective Norm & 1 & 5 & 3,189 & 0,559 \\
\hline 8 & Intention to do cash waqf & 1 & 5 & 4,083 & 0,414 \\
\hline
\end{tabular}

If we look at table 4 above, we can see that the average respondent chooses to agree on the Insan, Religiousity, Attitude Towards and Intention to do cash waqf questionnaire indicators. This can be seen from the average figure which is close to the maximum value. As for the questionnaire indicators on Trust, Knowledge, Perceived Behavior Control and also Subjective Norms, we can see that on average they choose to be neutral or between agree and disagree.

\section{Validity and Reliability Test}

Reliability and validity testing is required before testing structural models (Cooper \& Schindler, 2011a) \& (Riza \& Hafizi, 2019). The validity test is carried out by looking at the estimated value / loading factor, the item is said to be valid if the value is $>0.50$ and the reliability test is assessed using Cronbach Alpha, the variable construct is said to be reliable if the value is $>0.60$. In the validity test, there were several invalid question items, including the 6th variable religiosity indicator $(0.470)$, the 7 th religiosity variable question item (0.424) and the 1 st Knowledge variable question item (0.417). The three variables were eliminated and re-tested for validity. Table 5 shows that all variables in this study are valid and reliable because all items from all variables have met the requirements. Item validity is also considered good because all items are grouped in certain groups which confirm the theory. 


\begin{tabular}{|c|c|c|c|}
\hline Variable & Indicator & $\begin{array}{l}\text { Loading } \\
\text { Factor }\end{array}$ & $\begin{array}{l}\text { Cronbach } \\
\text { Alpha }\end{array}$ \\
\hline \multirow{5}{*}{$\begin{array}{l}\text { Perceived } \\
\text { Ihsan }\end{array}$} & It is important for me to benefit others & 0,665 & \multirow{5}{*}{0,800} \\
\hline & $\begin{array}{l}\text { It is important for me to show compassion for the } \\
\text { people who live on this earth }\end{array}$ & 0,793 & \\
\hline & It is important for me to show love to my family & 0,733 & \\
\hline & $\begin{array}{l}\text { It is important for me to show affection for my } \\
\text { neighbors }\end{array}$ & 0,691 & \\
\hline & Benefiting others makes me a true Muslim & 0,571 & \\
\hline \multirow{5}{*}{ Religiosity } & I believe in Allah SWT & 0,893 & \multirow{5}{*}{0,810} \\
\hline & $\begin{array}{l}\text { I always do my duty as Muslim (such as praying } 5 \\
\text { times a day and fasting is obligatory) }\end{array}$ & 0,629 & \\
\hline & Religion is very important to me & 0,833 & \\
\hline & $\begin{array}{l}\text { It is important for me to follow God's commands } \\
\text { seriously }\end{array}$ & 0,855 & \\
\hline & It is important for me to be kind to others. & 0,581 & \\
\hline \multirow{4}{*}{$\begin{array}{l}\text { Attitude } \\
\text { Towards }\end{array}$} & Doing cash waqf is beneficial for me & 0,756 & \multirow{4}{*}{0,850} \\
\hline & I have a positive perception of cash waqf & 0,817 & \\
\hline & $\begin{array}{l}\text { Conducting cash waqf is a wise and appropriate } \\
\text { step }\end{array}$ & 0,840 & \\
\hline & I like Cash Waqf because it is more practical & 0,692 & \\
\hline \multirow{4}{*}{ Trust } & $\begin{array}{l}\text { Sharia Financial Institutions The management of } \\
\text { cash waqf in Indonesia can be trusted }\end{array}$ & 0,890 & \multirow{4}{*}{0,904} \\
\hline & $\begin{array}{l}\text { I believe in Islamic financial institutions that } \\
\text { manage cash waqf }\end{array}$ & 0,935 & \\
\hline & I believe LKS-PWU can raise cash waqf & 0,861 & \\
\hline & $\begin{array}{l}\text { I believe that cash waqf can help achieve SDGs } 1 \\
\text { goal (eradicating all forms of poverty) }\end{array}$ & 0,675 & \\
\hline \multirow{3}{*}{ Knowledge } & I know the concept of cash waqf & 0,851 & \multirow{3}{*}{0,775} \\
\hline & I feel that I know quite a lot about cash waqf & 0,920 & \\
\hline & I have participated in cash waqf & 0,620 & \\
\hline \multirow{3}{*}{$\begin{array}{l}\text { Perceived } \\
\text { Behavior } \\
\text { Control }\end{array}$} & I can afford to donate money & 0,592 & \multirow{3}{*}{0,776} \\
\hline & $\begin{array}{l}\text { If I donate money, then I will contribute to poverty } \\
\text { alleviation (SDGs Goal 1) }\end{array}$ & 0,813 & \\
\hline & $\begin{array}{l}\text { The benefits of cash waqf make me want to donate } \\
\text { money }\end{array}$ & 0,834 & \\
\hline \multirow{3}{*}{$\begin{array}{l}\text { Subjective } \\
\text { Norm }\end{array}$} & People closest to me advised me to donate money & 0,911 & \multirow{3}{*}{0,892} \\
\hline & My family advised me to donate money online & 0,868 & \\
\hline & The media around me advised me to donate money & 0,795 & \\
\hline \multirow{3}{*}{$\begin{array}{l}\text { Intention To } \\
\text { Do Waqf }\end{array}$} & $\begin{array}{l}\text { I have the intention to donate money so that the } \\
\text { realization of cash waqf in Indonesia can be } \\
\text { optimal }\end{array}$ & 0,785 & \multirow{3}{*}{0,806} \\
\hline & $\begin{array}{l}\text { For the sake of realizing the goal of SDGs } 1 \\
\text { (eradicating all forms of poverty) I am very } \\
\text { interested in donating money }\end{array}$ & 0,923 & \\
\hline & I plan to donate money at least once in a lifetime & 0,612 & \\
\hline
\end{tabular}




\section{Assumption Test}

\section{Sample Adequacy Test}

The sample can be fulfilled if the amount of data in the study is 5 times the number of indicators (Hair et al., 2010). The question indicators compiled in this study amounted to 33 , then $33 \times 5=165$ respondents. Therefore, the sample required is a minimum of 165 respondents. In this study, there were 316 respondents who became the research sample, so it can be said that the sample needed is more than sufficient.

\section{Normality Test}

The SEM model has requirements for the fulfillment of the normality assumption. The normality test used in this study was carried out by observing the critical value of the assessment of normality test results from the IBM SPSS AMOS 24 program. Value outside the range $-1.96 \leq$ c.r $\leq 1.96$ or if loosened to $-2.58 \leq$ c.r $\leq 2.58$, it can be categorized as abnormal data distribution, therefore cases that do not meet these assumptions are not included in the next analysis. If the CR value on the skewness of the data is between -2.58 to 2.58 and the kurtosis value is $<7$, then the research data can be said to be normal (Ghozali, 2011). It can be seen in Table 7 that in general the data in this study were normally distributed.

Table 7 Normality Test

\begin{tabular}{|l|rrrrrr|}
\hline Variable & min & max & skew & c.r. & kurtosis & c.r. \\
\hline Intention 3 & 2,000 & 5,000 &,- 946 & $-6,868$ &,- 001 &,- 005 \\
Intention 2 & 1,000 & 5,000 &,- 255 & $-1,852$ &,- 620 & $-2,250$ \\
Intention 1 & 1,000 & 5,000 &,- 495 & $-3,591$ &, 108 &, 391 \\
PBC 3 & 2,000 & 5,000 &,- 312 & $-2,265$ &,- 693 & $-2,513$ \\
PBC 2 & 2,000 & 5,000 &,- 439 & $-3,183$ &,- 563 & $-2,043$ \\
PBC 1 & 1,000 & 5,000 &,- 008 &,- 058 &,- 285 & $-1,035$ \\
SN 3 & 1,000 & 5,000 &,- 083 &,- 602 &,- 257 &,- 934 \\
SN 2 & 1,000 & 5,000 &,- 007 &,- 048 &,- 302 & $-1,095$ \\
SN 1 & 1,000 & 5,000 &,- 073 &,- 530 &,- 180 &,- 655 \\
AT 4 & 2,000 & 5,000 &,- 332 & $-2,409$ &,- 980 & $-3,556$ \\
AT 3 & 2,000 & 5,000 &,- 506 & $-3,671$ &,- 323 & $-1,174$ \\
AT 2 & 2,000 & 5,000 &,- 667 & $-4,837$ &,- 009 &,- 032 \\
AT 1 & 2,000 & 5,000 &,- 649 & $-4,707$ &,- 360 & $-1,307$ \\
Trust 4 & 1,000 & 5,000 &,- 474 & $-3,442$ &,- 268 &,- 972 \\
Trust 3 & 1,000 & 5,000 &,- 160 & $-1,165$ &,- 576 & $-2,091$ \\
Trust 2 & 1,000 & 5,000 &,- 117 &,- 851 &,- 683 & $-2,480$ \\
Trust 1 & 1,000 & 5,000 &,- 153 & $-1,111$ &,- 204 &,- 739 \\
Religiosity 5 & 1,000 & 5,000 & $-3,108$ & $-22,556$ & 15,074 & 54,698 \\
Religiosity 4 & 1,000 & 5,000 & $-4,418$ & $-32,061$ & 24,590 & 89,226 \\
Religiosity 3 & 1,000 & 5,000 & $-4,654$ & $-33,777$ & 26,192 & 95,038 \\
Religiosity 2 & 1,000 & 5,000 & $-2,328$ & $-16,897$ & 6,284 & 22,803 \\
Religiosity 1 & 1,000 & 5,000 & $-6,278$ & $-45,557$ & 45,756 & 166,030 \\
Ihsan 1 & 1,000 & 5,000 & $-3,580$ & $-25,978$ & 18,037 & 65,451 \\
Ihsan 2 & 1,000 & 5,000 & $-2,390$ & $-17,341$ & 8,225 & 29,843 \\
Ihsan 3 & 1,000 & 5,000 & $-3,285$ & $-23,840$ & 13,901 & 50,440 \\
Ihsan 4 & 1,000 & 5,000 & $-1,397$ & $-10,138$ & 2,665 & 9,669 \\
\hline
\end{tabular}




\begin{tabular}{|l|rrrrrr|}
\hline Variable & $\min$ & $\max$ & skew & c.r. & kurtosis & c.r. \\
\hline Ihsan 5 & 1,000 & 5,000 & $-1,531$ & $-11,109$ & 1,958 & 7,104 \\
Know 4 & 1,000 & 5,000 &, 165 & 1,199 &,- 542 & $-1,966$ \\
Know 3 & 1,000 & 5,000 &, 061 &, 444 &,- 401 & $-1,454$ \\
Know 2 & 1,000 & 5,000 &,- 043 &,- 313 &,- 534 & $-1,937$ \\
Multivariate & & & & & 308,595 & 62,597 \\
\hline
\end{tabular}

\section{Test Suitability of Models and Hypotheses}

The goodness of fit model is assessed using several indicators. The use of multiple GOF indicators allows the researcher to accept acceptance of the proposed model (Hair et al., 2010). The GOF measure shows how well the resulting model produces a covariance matrix between the variable indicators. The GOF values in this study are as follows: The Chi-square value is 998,214 , the probability value is 0,000 , the marginal CFI value is 0.900 , the marginal TLI value is 0.888 , while the CMIN / $\mathrm{df}$ value is still classified as good with a value of 387 .

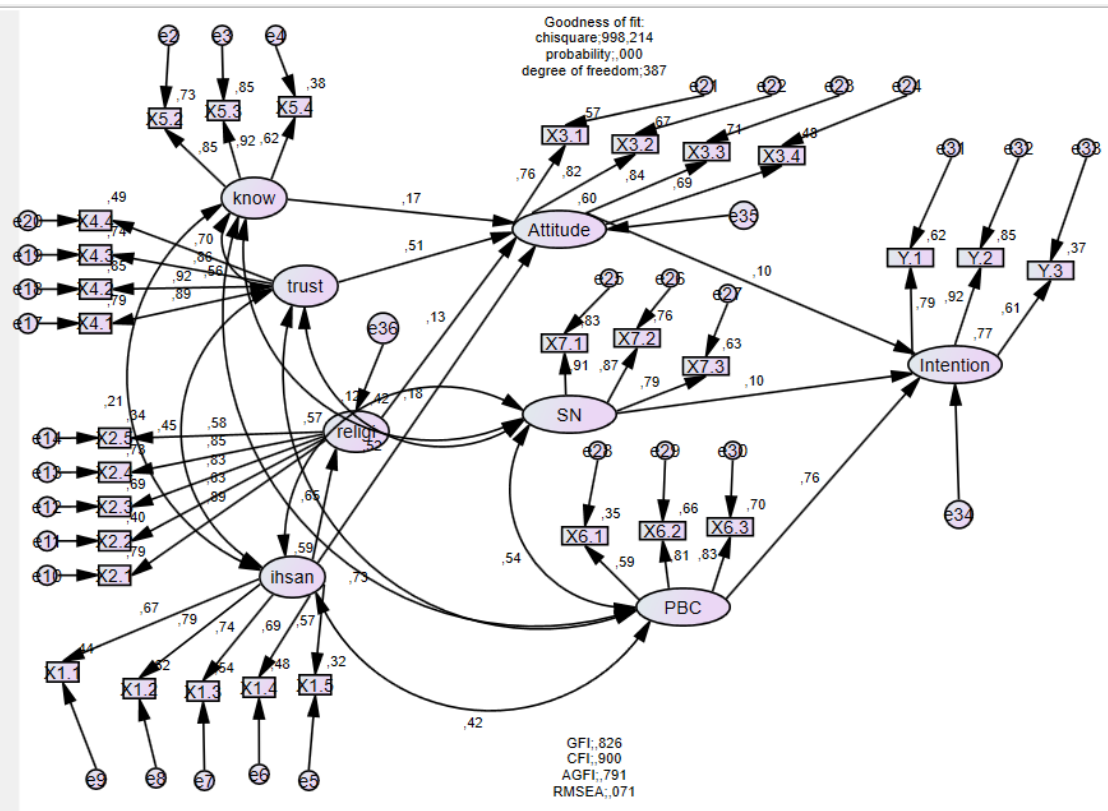

\begin{tabular}{|lll|c|c|c|c|c|}
\hline \multicolumn{3}{|c|}{ Effect } & Estimate & $\begin{array}{c}\text { Standard } \\
\text { Weight }\end{array}$ & C.R. & P & Label \\
\hline Religi & $<---$ & ihsan & 0,541 & 0,649 & 8,253 & $* * *$ & par_31 \\
\cline { 4 - 8 } Attitude & $<---$ & know & 0,117 & 0,173 & 2,916 & 0,004 & par_23 \\
\cline { 4 - 8 } Attitude & $<---$ & trust & 0,394 & 0,509 & 7,309 & $* * *$ & par_24 \\
\cline { 4 - 8 } Attitude & $<---$ & religi & 0,192 & 0,126 & 1,93 & $\mathbf{0 , 0 5 4}$ & par_25 \\
\cline { 4 - 8 } Attitude & $<---$ & ihsan & 0,223 & 0,177 & 2,306 & 0,021 & par_26 \\
\cline { 4 - 8 } Intention & $<---$ & SN & 0,068 & 0,095 & 1,804 & $\mathbf{0 , 0 7 1}$ & par_27 \\
Intention & $<---$ & PBC & 1,028 & 0,763 & 7,385 & $* * *$ & par_28 \\
\cline { 4 - 8 } Intention & $<---$ & Attitude & 0,121 & 0,097 & 1,465 & $\mathbf{0 , 1 4 3}$ & par_29 \\
\hline
\end{tabular}


Based on the estimation using the SEM Maximum Likelihood technique, not all hypotheses are supported empirically. As can be seen in Table 8, the value of the Standard Weight Regression construct value of Religiosity on Attitude has a value of 0.126, Subjective Norm on Intention has a value of 0.095 and Attitude to Intention has a value of 0.097 . Only five effects are significant with $p$ value $<0.005$, ihsan $\rightarrow$ religiosity, knowledge $->$ attitude, ihsan $->$ attitude and trust $->$ attitude and PBC -> intention.

\section{Hypothesis Testing}

1. The Perseption of One's Ihsan Affects the Level of Religiosity

The standard weight value of 0.649 is shown in the results of $\mathrm{H} 1$ analysis, meaning that the hypothesis is accepted. In line with previous research, (Khayat, 2006) (Rizal \& Amin, 2017) that a person's ihsan perception will affect his level of religiosity.

2. Ihsan's Perception Has a Significant Positive Effect on a Person's Attitude on Money Waqf

The standard weight value of 0.177 is shown in the results of $\mathrm{H} 2$ analysis, meaning that the hypothesis is accepted. This is in line with previous research, (Khan, 1986) and (Rizal \& Amin, 2017) in their research that shows a relationship between ihsan and a person's attitude. In this study, ihsan has an influence on a person's attitude in donating money waqf.

3. The Influence of the Level of Religiosity on a Person's Attitude on Cash Waqf The standard weight value is 0.126 which is more than 0.05 . This shows that the variable of religiosity does not positively affect a person's attitude towards cash waqf. This means that everyone who wants to do waqf does not need people who are 'pious or religiously obedient, but even ordinary people who are not' religious can do waqf. So that $\mathrm{H} 3$ which reads "The level of religiosity has a significant positive effect on a person's attitude towards cash waqf" cannot be accepted.

4. A Person's Trust in Waqf Nazhir Institutions has a Significant Positive Effect on a Person's Attitude Towards Waqf

The standard weight value of 0.509 is shown in the results of the H4 analysis, meaning that the hypothesis is accepted. In line with previous research (Doney \& Cannon, 1997) and (Awaliah Kasri, 2013) found that a relationship between a person's belief in a humanitarian charity will increase their attitude towards the desire to provide donations / assistance through that institution. In this study, public trust in the nazhir waqf institution will increase their attitude towards waqf, especially cash waqf.

5. A Person's Level of Knowledge about Money Waqf has a Significant Positive Effect on His Attitude on Money Waqf

The standard weight value of 0.173 is shown in the results of the H5 analysis, meaning that the hypothesis is accepted. This is in line with the findings (Asmalia, 
Awaliah Kasri, et al., 2018) and (Othman et al., 2017) regarding the level of knowledge having an influence on a person's attitude to make donations / the like. In this case, we can conclude that many people already understand about cash waqf.

6. Perceptions of Control A Person's Behavior towards Cash Waqf has a Positive Effect on A Person's Intention to Do Cash Waqf

The standard weight value of 0.763 is shown in the results of the H6 analysis, meaning that the hypothesis is accepted. This is in line with the main theory of TPB put forward by (Ajzen, 1991), that perceived behavior control has an influence on intention.

7. The Influence of Subjective Norms on Intention

The standard weight value is 0.095 , which is more than 0.05 . This shows that the subjective norm variable does not positively affect a person's intention to waqf money. That is, a person's belief that is formed by another person cannot support the intention or is a prerequisite for doing cash waqf. So that the H7 which reads "Subjective Norms for a person towards cash waqf has an influence on one's intention to do cash waqf" cannot be accepted.

\section{Effect of Attitude on Intention}

The standard weight value is 0.097 , which is more than 0.05 . This shows that the attitude variable does not positively affect a person's intention to do cash waqf. This means that intention is not influenced by subjective attitudes and norms, becomes and does not become a significant predictor of compliance with waqf paying behavior. So that the H8 which reads "Subjective Norms for a person towards cash waqf has an influence on one's intention to do cash waqf" cannot be accepted.

\section{Cash Waqf and 1st SDGs}

Cash waqf and waqf through money are two different things, on its website the Indonesian Waqf Board (Indonesian Waqf Board, 2016) explains that cash waqf is a pure waqf using the currency prevailing in the State of Indonesia, its nature is eternal and its value will not run out because it is productive, not consumptive. While waqf through money is a waqif that gives money to the waqf nazhir to buy goods or to carry out waqf programs / projects that are social or consumptive in nature. After knowing these two terms, it is clear that the projection of cash waqf is very bright in the future.

The projection (Nasution \& Hasanah, 2006) regarding the potential for cash waqf is very large, even some other researchers have further examined the potential for even greater cash waqf. As explained in the background, if it is estimated that the number of generous Muslims is 10 million with an average income of $\mathrm{Rp} 500,000$ to $\mathrm{Rp}$ $10,000,000$, then the estimated calculation of the waqf funds collected is around 3 trillion per year. If this potential can be fully realized, the poverty rate in Indonesia will definitely decrease and there will be no more poor people in Indonesia. There is 
still a big question, why this potential cannot be optimized or even realized.

However, after conducting this research, with insignificant Attitude to Intention, it is clear that public awareness of the importance of cash waqf is still very minimal. The attitude of the Indonesian people towards cash waqf is still not good, meaning that it is still half-hearted. It is a big homework for all elements of society, especially Muslims, to optimize the potential of cash waqf for the success of SDGs 1, namely alleviating all forms of poverty. Mustadhafiin must continue to be empowered.

SDG-1 which sets out the global challenge to end poverty is also an indicator of the target rectum of waqf according to Islamic guidelines. As a good Islamic character or waqf, waqf has two benefits for worshipers who seek mercy and emancipation and hope to be blessed by the Almighty. The resources he donates for the use of others, especially serious causes and social welfare beliefs, can be partially channeled to government reduction programs aimed at achieving the holistic social well-being of the SDGs. Waqf resources which are severely underutilized through formulating policies and strategies can effectively meet SDG-1 targets if waqf is given priority among policy makers, people who are immediately aware, aware of property from illegal occupation, are mobilized and enhanced. Further research is strongly suggested as the assets and liabilities of waqf resources are not renewed and the formulation of policies and pro programs following divine guidelines requires great attention.

\section{Reviewing Cash Waqf in Various Countries}

As previously explained, recently cash waqf has returned to add to the repertoire of knowledge and financing options in the Islamic economy. The popularity of cash waqf occurred after Professor Mannan socialized it in Bangladesh through Social Investment Bank Limited (SIBL) (Ibrahim et al., 2013). SIBL produces cash waqf certificates to collect funds from the rich and share the cash waqf it has collected with the poor. Bangladesh, which originally had a poor population of $88 \%$, is now slowly starting to decrease in line with the SIBL policy (Al Zobair \& Hoque, 2019).

\section{Conclusion and Recommendation}

The results of the research stated that not all of the formulated hypotheses could be accepted, namely there were 3 hypotheses that were not accepted; H3, H7, and H8. Overall, the results of this study indicate that the Indonesian Muslim community has a response intention, a good attitude and an interest in cash waqf to support the goals of sustainable development (SDGs).

This study found four latent variables that affect attitudes towards waqf, namely knowledge of waqf, religiosity, ihsan, and trust in waqf institutions. In addition, it is found that perceived behavioral control affects Muslim intention to pay waqf. It also implies that knowledge, religiosity, and belief have an indirect influence on the intention to pay waqf. This is in line with previous research conducted on the influence of the latent variables mentioned earlier on intention to pay waqf (Othman et al., 2017) \& (Hanifah et al., 2020).

In general, this study confirms the suitability and application of TPB in the context 
of waqf. The variables highlighted in the TPB, such as attitudes, subjective norms, and perceived behavioral control and intentions, play an important role in explaining behaviors towards waqf payment.

The research findings have implications for theory and practice. Compared to previous studies, this study found that subjective norms did not have a very high influence on intention to pay zakat, whereas perceived behavioral control was one of the biggest factors along with attitude.

In terms of theoretical implications, the findings suggest that subjective norm construction and perceived behavioral control cannot be generalized to all types of objects of the study environment and population. In terms of practical implications, waqf institutions need to put more effort into encouraging Muslims to pay for waqf through waqf institutions. Since religiosity and perceived behavioral control are two factors that primarily influence the intention to pay waqf, it is important for zakat institutions to promote the value of religiosity and ease of access for waqf payers.

Based on the estimates made in this study, waqf funds were also found to have the potential to support the achievement of the SDGs in Indonesia. These findings highlight the potential of waqf in supporting the achievement of the SDGs in Indonesia, something that may be of use to the government, NGOs, zakat organizations, and other waqf stakeholders.

Based on the research findings, when viewed from the rejected hypotheses, the researcher concludes that the lack of public literacy about cash waqf is the dominant factor, this is evidenced by the rejected H8. Where the influence of the surroundings, both from the family and the environment can affect the perception of the usefulness of donating money. Another evidence is based on the results of our research on H7 which was rejected, where the influence of the surroundings, both from the family and the surrounding environment, can influence people's attitudes to do cash waqf.

The researcher offers a solution for the government and stake holders who are directly involved in cash waqf to be able to provide education about cash waqf to the public, especially for the millennial generation. By promoting it through cash waqf go to campus events or socializing it through social media so that it can be easily accepted.

Cash waqf is a relatively new thing, therefore in addition to increasing the intensity of promotion of cash waqf. Researchers recommend that the government cooperate with Islamic banks that receive cash waqf money to disseminate the concept of payment for waqf money that is easier, more efficient, and follows the trends of the times.

\section{References}

[1]Ajzen, I. (2002). CONSTRUCTING A THEORY OF PLANNED BEHAVIOR QUESTIONNAIRE.7.

[2]Ajzen, I. (2005). Attitudes, Personality and Behaviour, 2nd edition (2nd ed.). McGrawHill.

[3]Ajzen, I. (1991). The theory of planned behavior. Organizational Behavior and Human 
Decision Processes, 179-211.

[4]Ajzen, I., \& Madden, T. J. (1986). Prediction of goal-directed behavior: Attitudes, intentions, and perceived behavioral control. Journal of Experimental Social Psychology, 22(5), 453-474. https://doi.org/10.1016/0022-1031(86)90045-4

[5]Al Jaffri Saad, R., \& Haniffa, R. (2014). Determinants of zakah (Islamic tax) compliance behavior. Journal of Islamic Accounting and Business Research, 5(2), 182-193. https://doi.org/10.1108/JIABR-10-2012-0068

[6]Al Zobair, Md. A., \& Hoque, M. A. (2019). Role of Waqf to Attain the "SDG-1: Ending Poverty" in Bangladesh. In K. M. Ali, M. K. Hassan, \& A. elrahman E. S. Ali (Eds.), Revitalization of Waqf for Socio-Economic Development, Volume II (pp. 15-34). Springer International Publishing. https://doi.org/10.1007/978-3-03018449-0_2

[7]Al-Qardhawi, Y. (1981). Economic Security in Islam (1st ed.). Dar Al Wahi Publication. [8]Ambrose, A. H. A. A., Gulam Hassan, M. A., \& Hanafi, H. (2018). A proposed model for waqf financing public goods and mixed public goods in Malaysia. International Journal of Islamic and Middle Eastern Finance and Management, 11(3), 395-415. https://doi.org/10.1108/IMEFM-01-2017-0001

[9]Andri Soemitra. (2018). Peran Pemberdayaan Masyarakat oleh Lembaga Keuangan Mikro Syariah dalam Perspektif Sustainable Development Goals (SDGs).

[10]Arif, S. (2010a). REDISTRIBUSI KEUANGAN ISLAM. La_Riba, IV, 85-115.

[11]Arif, S. (2010b). Wakaf Tunai Sebagai Alternatif Mekanisme Redistribusi $\begin{array}{llll}\text { Keuangan } \quad \text { Islam. } & \text { La_Riba, }\end{array}$ https://doi.org/10.20885/lariba.vol4.iss1.art6

[12]Asmalia, S., Awaliah Kasri, R., \& Ahsan, A. (2018). Exploring the Potential of Zakah for Supporting Realization of Sustainable Development Goals (SDGs) in Indonesia. International Journal of Zakat, 3(4), 51-69. https://doi.org/10.37706/ijaz.v3i4.106

[13]Asmalia, S., Kasri, R. A., \& Ahsan, A. (2018). Exploring the Potential of Zakah for Supporting Realization of Sustainable Development Goals ( SDGs ) in Indonesia. International Journal of Zakat: Special Issue on Zakat Conference, 3(4), 51-69.

[14]Awaliah Kasri, R. (2013). Giving behaviors in Indonesia: Motives and marketing implications for Islamic charities. Journal of Islamic Marketing, 4(3), 306-324. https://doi.org/10.1108/JIMA-05-2011-0044

[15]Awaliah Kasri, R., \& Ramli, U. H. (2019). Why do Indonesian Muslims Donate Through Mosques? Emerald Insight, 12(5). https://doi.org/10.118/IMEFM-112018-0399

[16]Bandura, A. (1982). Self-efficacy mechanism in human agency. American Psychologist, 37(2), 122-147. https://doi.org/10.1037/0003-066X.37.2.122

[17]Bassir, N. F., Zakaria, Z., Hasan, H. A., \& Alfan, E. (2014). FACTORS INFLUENCING THE ADOPTION OF ISLAMIC HOME FINANCING IN MALAYSIA. 25.

[18]Carabain, C. L., \& Bekkers, R. (2011). Religious and secular volunteering: A comparison between immigrants and non-immigrants in the Netherlands. 
Voluntary Sector Review, 2(1), 23-41. https://doi.org/10.1332/204080511X560602

[19]Chapra, M. U. (2008). The Islamic Vision of Development in the Light of Maqasid alShariah. The International Institute of Islamic Thought.

[20]Cialdini, R. B., Kallgren, C. A., \& Reno, R. R. (1991). A Focus Theory of Normative Conduct: A Theoretical Refinement and Reevaluation of the Role of Norms in Human Behavior. Advances in Experimental Social Psychology, 24(C), 201-234. https://doi.org/10.1016/S0065-2601(08)60330-5

[21]Cooper, D., \& Schindler. (2011a). Business Research Methods, Eleventh Edition (11th ed.). McGraw-Hill.

[22]Cooper, D., \& Schindler, P. (2011b). Business Research Methods. 11th Edition. McGraw Hill.

[23]Databoks. (2020). Berapa Jumlah Penduduk Miskin Indonesia? I Databoks. https://databoks.katadata.co.id/datapublish/2020/04/08/berapa-jumlahpenduduk-miskin-indonesia

[24]Doney, P. M., \& Cannon, J. P. (1997). An Examination of the Nature of Trust in Buyer-Seller Relationships. Journal of Marketing, 61(2), 35. https://doi.org/10.2307/1251829

[25]Ghozali, I. (2011). Aplikasi Analisis Multivariate Dengan Program IBM SPSS 19 edisi 5 (5th ed.). UNDIP.

[26]Hair, J. F., Black, W. C., Babin, B. J., \& Rolph E, A. (2010). Multivariate Data Analysis: A Global Perspective (7th ed.). Pearson Education.

[27]Hanifah, I. N., Yuri, A., Wahyudi, R., \& Rifan, A. A. (2020). Analisis Knowledge, Attitude, And Practice (KAP) terhadap Manajemen Keuangan Masjid di D.I.Yogyakarta. ECOPLAN: JOURNAL OF ECONOMICS AND DEVELOPMENT STUDIES, 3(1), 17-21. https://doi.org/10.20527/ecoplan.v3i1.78

[28]Ibrahim, H., Amir, A., \& Masron, T. A. (2013). Cash Waqf: An Innovative Instrument for Economic Development. 6(1), 7.

[29]Indonesian Waqf Board. (2016, October 12). Wakaf Untuk Kesejahteraan dan Kemartabatan. Badan Wakaf Indonesia (BWI). https://www.bwi.go.id/

[30]Johnson, B. R., Larson, D. B., De Li, S., \& Jang, S. J. (2000). Escaping from the crime of inner cities: Church attendance and religious salience among disadvantaged youth. Justice Quarterly, 17(2), 377-391. https://doi.org/10.1080/07418820000096371

[31]Khan, M. F. (1986). Macro Consumption Function in an Islamic Framework. In M. A. Choudhury, Contributions to Islamic Economic Theory (pp. 140-165). Palgrave Macmillan UK. https://doi.org/10.1007/978-1-349-07728-1_11

[32]Khayat, D. A. A. (2006). TAWARRUQ, ITS CONCEPTS, ITS PRACTICES AND ITS ECONOMICS IMPLICATION ON ITS PROMOTION BY ISLAMIC BANKS. 10.

[33]Margono. (2010). Metodologi Penelitian Pendidikan. Rineka Cipta.

[34]Nafis, C. (2009). WAKAF UANG UNTUK JAMINAN SOSIAL. Al-Awqaf, 02, 31.

[35]Nasution, \& Hasanah, U. (2006). Wakaf Tunai Inovasi Finansial Islam. Pusat Kajian Timur Tengah dan Islam Universitas Indonesia.

[36]Nasution, M. E., \& Hasanah, U. (2005). Wakaf tunai: Inovasi finansial Islam: Peluang 
dan tantangan dalam mewujudkan kesejahtraan umat. Pusat Kajian Timur Tengah dan Islam Universitas Indonesia,. (1st ed.). Pusat Kajian Timur Tengah dan Islam, Universitas Indonesia.

[37]Othman, Y. H.-, Alwi, I., Yusuff, M. S. S., \& Saufi, M. S. A. M. (2017). The Influence of Attitude, Subjective Norm, and Islamic Religiosity on Compliance Behavior of Income Zakat Among Educators. International Journal of Academic Research in Business and Social Sciences, 7(11), Pages 1110-1116. https://doi.org/10.6007/IJARBSS/v7-i11/3549

[38]Pratama, Y. C. (2015). Analisis Faktor-Faktor Yang Mempengaruhi Kemiskinan Di Indonesia. Esensi, 4(2), 210-223. https://doi.org/10.15408/ess.v4i2.1966

[39]Ramdhani, N. (2011). Penyusunan Alat Pengukur Berbasis. BULETIN PSIKOLOGI, 15.

[40]Riza, A. F., \& Hafizi, R. (2019). Customers attitude toward Islamic mobile banking in Indonesia: Implementation of TAM. 1(2), 10.

[41]Rizal, H., \& Amin, H. (2017). Perceived Ihsan , Islamic egalitarianism and Islamic religiosity towards charitable giving of cash waqf. Journal of Islamic Marketing, 8(4), 669-685. https://doi.org/10.1108/JIMA-05-2015-0037

[42]Sachs, J. D. (2015). Goal-based development and the SDGs: Implications for development finance. Oxford Review of Economic Policy, 31(3-4), 268-278. https://doi.org/10.1093/oxrep/grv031

[43]Sandıkcı, Ö., \& Rice, G. (2011). Handbook of Islamic Marketing. Edward Elgar Publishing. https://doi.org/10.4337/9780857936028

[44]Saptono, I. T. (2019). Peluang Dan Tantangan Wakaf Di Era 4.0. 10.

[45]Sekaran, U., \& Bougie, R. (2003). Research Methods For Business: A Skill Building Approach. Seventh Edition. John Wiley \& Sons.

[46]Sholihin, M., \& Ratmono, D. (2013). Analisis SEM-PLS dengan Warp PLS 3.0 untuk Hubungan Nonlinier dalam Penelitian Sosial dan Bisnis. CV. Andi.

[47]Souiden, N., \& Rani, M. (2015). Consumer attitudes and purchase intentions toward Islamic banks: The influence of religiosity. International Journal of Bank Marketing, 33(2), 143-161. https://doi.org/10.1108/IJBM-10-2013-0115

[48]Statistics Indonesia. (2019). Persentase Penduduk Miskin Maret 2019 Sebesar 9,41 Persen. https://www.bps.go.id/pressrelease/2019/07/15/1629/persentasependuduk-miskin-maret-2019-sebesar-9-41-persen.html

[49]Syafiq, A. (2014a). Wakaf tunai untuk pemberdayaan usaha kecil. Journal IAIN Kudus, 25.

[50]Syafiq, A. (2014b). WAKAF TUNAI UNTUK PEMBERDAYAAN USAHA KECIL. 1(2), 25.

[51]Waluyo, M. (2016). Mudah Cepat Tepat Penggunaan Tools Amos Dalam Aplikasi (SEM) (1st ed.). UPN “Veteran" Jawa Timur.

[52]White, S. W., \& Roberson-Nay, R. (2009). Anxiety, social deficits, and loneliness in youth with autism spectrum disorders. Journal of Autism and Developmental Disorders, 39(7), 1006-1013. https://doi.org/10.1007/s10803-009-0713-8 